\title{
RDUS
}

Revue de DROIT

UNIVERSITÉ DE SHERBROOKE

Titre : $\quad$ CANADA'S NEW IMMIGRATION ACT: AN AFFRONT TO THE CHARTER AND CANADA'S COLLECTIVE CONSCIENCE?

Auteur(s) : $\quad$ Mark Anthony DRUMBL

Revue : $\quad$ RDUS, 1993-1994, volume 24, numéro 2

Pages: $\quad 385-432$

ISSN : $\quad 0317-9656$

Éditeur : $\quad$ Université de Sherbrooke. Faculté de droit.

URI : $\quad$ http://hdl.handle.net/11143/13375

DOI : https://doi.org/10.17118/11143/13375 
Page vide laissée intentionnellement. 


\title{
COMMENTAIRE
}

\section{CANADA'S NEW IMMIGRATION ACT: AN AFFRONT TO THE CHARTER AND CANADA'S COLLECTIVE CONSCIENCE?}

\author{
par Mark Anthony DRUMBL*
}

Cet article examinera la constitutionnalité du paragraphe 46.01(1) et du sous-alinéa 19(1)(c.1)(i) de la Loi sur l'immigration. Le paragraphe 46.01(1) prévoit que sont désormais exclus du processus de détermination du statut de réfugié au Canada tous ceux qui sont passés par un tiers pays «sûr» pour arriver au Canada, à la seule exception de ceux qui ne s'y trouvaient qu'en vue d'un vol de correspondance. En vertu de l'art. 19(1)(c.1)(i), toute revendication du statut de réfugié au Canada est irrecevable si l'intéressé a commis une infraction criminelle dans son pays d'origine. L'auteur soutient que ces dispositions violent les garanties procédurales de justice fondamentale prévues à l'article 7 de la Charte canadienne des droits et libertés. De plus, il soulève la possibilité que les droits conférés aux articles 11(d), 11(g), 12, 14 et 15(1) sont également enfreints par la Loi sur l'immigration. Ensuite, il aborde la question de savoir si ces violations constituent des limites raisonnables au sens de l'article premier de la Charte. Etant donné que les questions relatives à la politique d'immigration se trouvent actuellement au centre de nos débats de société, il devient de plus en plus difficile de maintenir l'équilibre entre les buts de la Loi et les obligations imposées sur le Canada par la Charte et par la Convention des nations unies relative aux réfugiés. Malgré cette difficulté, l'auteur suggère plusieurs façons par lesquelles la Loi peut être amendée pour respecter cette équilibre.

*. Master of Arts (McGill University), LL.B. (University of Toronto), law clerk to Mr. Justice Frank Iacobucci, Supreme Court of Canada, 1994-95. 
This essay explores the constitutionality of sections 46.01(1) and 19(1)(c.1)(i) of the federal Immigration Act. These sections empower immigration officials to exclude from the refugee determination process any claimant who has arrived in Canada via a "safe» third country or who has been determined to have committed a criminal offence in the home country, unless the claimant falls into several narrow exceptions provided by the statute. The author submits that these provisions violate the procedural requirements of fundamental justice guaranteed by section 7 of the Canadian Charter of Rights and Freedoms. A further investigation is made as to whether these statutory provisions offend the specific rights provided by sections $11(\mathrm{~d}), 11(\mathrm{~g}), 12,14$ and 15(1). As well, the essay addresses the question as to whether ss. 46.01(1) and 19(1)(c.1)(i) can constitute reasonable limits under Charter section 1. Ultimately, the author proposes several suggestions as to how these sections can be amended so as to ensure that they attain their policy objectives while respecting both the Charter and the United Nations Convention Relating to the Status of Refugees. As immigration issues are increasingly thrust into the public policy arena, maintaining this balance could become problematic, yet nonetheless important. 


\section{TABLE OF CONTENTS}

A. INTRODUCTION . . . . . . . . . . . . . . . . . . . . . . . 389

B. POLITICAL BACKGROUND $\ldots \ldots \ldots \ldots \ldots \ldots \ldots \ldots$

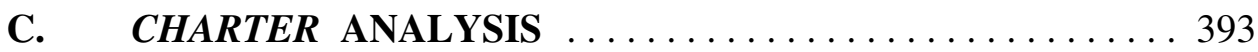

I. THE «SAFE THIRD COUNTRY» PROVISIONS . . . . 394

SECTION $12 \ldots \ldots \ldots \ldots \ldots \ldots \ldots \ldots \ldots \ldots \ldots$

SECTION $7 \ldots \ldots \ldots \ldots \ldots \ldots \ldots \ldots \ldots \ldots \ldots, \ldots \ldots \ldots$

SECTION $15 \ldots \ldots \ldots \ldots \ldots \ldots \ldots \ldots \ldots \ldots . \ldots 413$

II. THE «PRIOR CRIMINAL RECORD» PROVISIONS . . 415

III. BEING PART OF AN «ORGANIZATION ENGAGED

IN ESPIONAGE, SUBVERSION OR TERRORISM» . . 421

IV. JUSTIFICATION UNDER SECTION 1 OF THE CHARTER ........................... 423

a) SAFE THIRD COUNTRY ............ 424

i) CO-ORDINATED INTERSTATE APPROACH ............... 424

ii) EXPEDITING AND STREAMLINING THE PROCESS ............... 427

b) PRIOR CRIMINAL RECORD AND SUBVERSIVE ORGANIZATION ......... 429

D. FILLING THE VOID $\ldots \ldots \ldots \ldots \ldots \ldots \ldots \ldots \ldots, 431$

E. CONCLUSION $\ldots \ldots \ldots \ldots \ldots \ldots \ldots \ldots \ldots \ldots \ldots \ldots \ldots \ldots$ 
Canada's new Immigration Act : an affront to the Charter and (1994) 24 R.D.U.S. Canada's collective conscience? 
Canada's new Immigration Act :

\section{A. INTRODUCTION}

On December 17, 1992, An Act to Amend the Immigration Act and Other Acts in Consequence Thereof (Bill C-86) ${ }^{1}$ received royal assent. ${ }^{2}$ Bill C-86 significantly changes Canada's immigration law by making it more difficult for refugees to process their claims in Canada. ${ }^{3}$ In fact, the amendments empower the Senior Immigration Officer (the front line state agent in the immigration process) to expel a claimant who falls into certain categories created by the law.

The most significant barriers to having one's claim heard in Canada are found in ss. 46.01(1) and 19(1)(c.1)(i) of the amended Act. Section 46.01(1) stipulates that any refugee arriving at Canada's borders through a «safe third country» will automatically be denied a refugee determination hearing in Canada and will be returned to that safe third country. Section 19(1)(c.1)(i) mandates a Senior Immigration Officer (SIO) to exclude from Canada any refugee claimant who has committed a criminal offence in his/her ${ }^{4}$ home country. The only restriction on the scope of 19(1)(c.1)(i) is that the offence be recognized in Canada. Moreover, this section operates in conjunction with s. 19(1)(e) which excludes from the Canadian refugee determination process any member of an organization which is reasonably believed to be involved in terrorist activity.

This essay will analyze the constitutionality of these provisions in light of the broad protection of human rights enshrined in the Canadian Charter of Rights and Freedoms ${ }^{5}$. Ever since the decision of the Supreme Court of Canada in Singh v. Minister of Employment and Immigration ${ }^{6}$, it has been recognized

1. Third Session, Thirty-Fourth Parliament, 40-41 Elizabeth II, 1991-92.

2. It took effect on February 1, 1993.

3. Some statistics might be helpful. In 1991, 14,495 Convention Refugees were admitted into Canada as government sponsored refugees; another 3186 were privately sponsored; the median age was in the 25 to 29 bracket: Immigration Canada, Immigration Statistics, 1991, Ministry of Supply and Services, 1992.

4. A note on the writing style of the essay. In order to reflect gender neutrality and encourage stylistic cogency, this essay will randomly alternate third person references in the masculine and feminine pronouns instead of the «s/he» or «her/his» constructions.

5. Part I of the Constitution Act, 1982, being Schedule B to the Canada Act, 1982 (U.K.), 1982 c. 11 [hereafter the Charter].

6. [1985] 1 S.C.R. 177; 58 N.R. 1 [hereafter Singh]. 
that Charter rights vest in any individual physically present in Canada. ${ }^{7}$ Charter rights thus inure in all refugee claimants on Canadian soil, whether their entry to Canada was legal or not. This essay will argue that Bill C-86 not only violates a refugee claimant's constitutional rights, but also the right guaranteed to refugees by international covenants not to be sent to a place where one's life or security would be threatened.

Attention will not only be focussed on the legal issues involved, but also on the broad array of political interests that operate within the domain of immigration policy. Canada's acceptance of its international responsibility to mitigate the plight of involuntary migrants was recognized in 1987 when the international community awarded the Canadian people the Nansen medal for outstanding achievements on behalf of the world's refugees. ${ }^{8}$ In so far as Bill C-86 curtails our international responsibilities, its philosophical underpinnings must be questioned.

The potential Charter ss. 7, 12 or 15 violations created by the safe third country and the prior criminal record provisions shall be separately considered. Subsequently, this essay shall discuss whether either set of provisions can constitute a reasonable limit under section 1 . In short, it seems that the effect of the prior criminal record provisions is more likely to violate the Charter than those related to the safe third country. The Charter right most susceptible to violation is the s. 7 guarantee of procedural fairness. It is less clear whether these provisions inflict «cruel and unusual treatment» on a claimant; nevertheless, interesting questions arise whether the fact that they significantly increase the risk of such treatment being inflicted can in and of itself violate section 12 . If the impugned sections of Bill C-86 are deemed unconstitutional, this essay proposes that judicial initiative can reword these provisions to give effect to the

7. The jurisprudence holds that sections 2 and 7 to 15 clearly apply to such persons. Nevertheless, there is political opposition to such a position. For example, during the political campaign leading up the the October 25, 1993 federal election, the Reform Party indicated that it would consider enacting a policy that would remove Charter protection from immigration claimants: «A vote for Canada's future», Montréal Gazette, Wednesday October 20, 1993, p. B2.

8. Thanks to Susan MacDonald, Faculty of Law, University of Toronto, for this point. 
Canada's new Immigration Act :

rights of refugee claimants as well as to promote the legitimate policy objectives behind the Act.

\section{B. POLITICAL BACKGROUND}

«Quite frankly, Canadians are fed up with people trying to beat the system. This Bill addresses that frustration in Canadian society.»"

\section{-- Hon. Doug Lewis, Former Solicitor General}

Bill C-86 is the product of many years of discussion, committees and legislative drafting. ${ }^{10}$ When the Progressive Conservatives assumed a majority government in 1984, they pledged to revamp Canada's immigration system. ${ }^{11}$ Their vision -- which animates not only Bill C-86 and regulations made thereto, but also other legislation ${ }^{12}$-- rests on three pillars. ${ }^{13}$ Firstly, Canada must strive to make a «better selection» of candidates for immigration through closer monitoring of categories and numbers of immigrants. Secondly, the immigration system should be imbued with more stringent control mechanisms to protect Canada's domestic security and guard against abuse of social services. Lastly,

9. Hansard, 132:163 at 12533, June 22, 1992.

10. A nascent version of the reforms eventually promulgated in Bill C-86 is contained in Refugee Perspectives, 1987-88, Refugee Affairs Division, (Ottawa: The Division, 1988). Bill C-86 was itself first introduced in the summer of 1992, and passed through the three Parliamentary readings fairly quickly, not for want of debate, but rather because the government limited the time available to discuss the proposed legislation.

11. The Hon. Flora MacDonald, the then Minister of Employment and Immigration, announced in Parliament on November 23, 1984 that «...le gouvernement [veut] réexaminer la Loi de l'immigration et les niveaux d'immigration»: Hansard, Volume 1 (1984) at 533. And, at 408, in a discussion of the reevaluation of immigration quotas for 1985, she stated that: «Nous entendons examiner en profondeur la politique d'immigration...nous nous pencherons donc sur les niveaux d'immigration en fonction des besoins de notre pays», (November 20, 1984).

12. For example, «...the government is also proposing to streamline administrative procedures involved in issuing or renewing documents for visitors, students and returning residents», John Shields, Parliamentary Secretary to the Minister of Employment and Immigration, Hansard, 132:163 at 12505, June 22, 1992.

13. Hon. Bernard Valcourt, Minister of Employment and Immigration, in Hansard, 132:180 at 13911, November 24, 1992. 
the immigration and refugee determination systems should be streamlined in order to render fair decisions more quickly.

Thus, it is clear that reform of the refugee determination system is not the main priority of Bill C-86. Instead, the focus is on reducing immigration to Canada. Certain regulations already passed under the new Immigration Act serve the dual function of reducing the number as well as diversity of immigrants. The government seeks wealthier and better educated immigrants:

«[We need] a renewed emphasis on the independent and business class immigrant whose skills, talents and acumen are so necessary to our economic prosperity.» ${ }^{14}$

In order to attain this goal, the «education regulation» was passed in May 1993. ${ }^{15}$ In order to be admitted as an independent immigrant, a claimant must now obtain 70 points out of 100 on the Ministry's new test. A university degree is worth 15 points, and knowledge of English or French nets an additional 15 points. A candidate without a secondary school degree receives no points; a claimant with no proficiency in either English or French also receives no points.

The scope of who can qualify as a refugee claimant has also been narrowed. Reducing the number of refugees is seen to support the policy goals behind Bill C-86 since refugees generally have less education, English/French skills and financial resources than immigrants from «safe» countries.

When Opposition members ${ }^{16}$ suggested that Bill C-86 was unnecessarily harsh, Conservative Ministers often responded that Canadians had to establish «better control over [our] immigration and refugee programs». ${ }^{17}$ References were frequently made to international criminals who allegedly enter the country due to the laxness of Canadian immigration requirements. Another popular

14. Hon. Jean Corbeil, Minister of Transport, in Hansard, 132:163 at 12497, June 22, 1992.

15. Donn Downey, «Canada to tighten immigration laws», Globe \& Mail, May 26, 1993, p. A4.

16. Most notably Warren Allmand and Dan Heap, respectively the Liberal and NDP immigration policy critics.

17. Hansard, 132:180 at 13911, November 24, 1992. 
image was that of the refugee who fraudulently weighs down Canada's welfare system. ${ }^{18}$ Although an open-door immigration policy may once have been acceptable, many proponents of Bill C-86 now feel it is no longer so. As voiced by Jean Corbeil, Minister of Transport:

«Much has developed in the sixteen years since the Immigration Act was passed... global political and economic conditions are far from stable...the system was not designed to withstand the pressures exerted on it by the realities of the 1990's.» ${ }^{19}$

Such is the political background to Bill C-86. A discussion of the constitutionality of its refugee determination provisions shall demonstrate that much of the discourse supporting the legislation is flawed. Although there are some legitimate policy objectives (and this essay will try to flesh these out), they are often lost in a sea of rhetoric. The social and economic problems currently plaguing Western societies cannot be blamed on newcomers and refugees. Doing so obfuscates the real issues at hand and reduces the effectiveness of potential solutions.

\section{CHARTER ANALYSIS}

The relevant sections of the Charter are as follows:

7. Everyone has the right to life, liberty and security of the person and the right not to be deprived thereof except in accordance with the principles of fundamental justice.

11. Any person charged with an offence has the right

(d) to be presumed innocent until proven guilty according to law in a fair and public hearing by an independent and impartial tribunal;

18. John McDermid, Minister of State (Finance and Privatization): «There have been some problems with fraud, not only in the immigration end of things but from that it goes into welfare fraud...», Hansard, 132:163 at 12502, June 22, 1992. This vision has also partly animated the recent decision by the Liberal government to issue special identification cards for immigrants.

19. Hansard, 132:163 at 12496, June 22, 1992. 
(g) not to be found guilty on account of any act or omission unless, at the time of the act or omission, it constituted an offence under Canadian or international law or was criminal according to the general principles of law recognized by the community of nations.

12. Everyone has the right not to be subjected to any cruel and unusual treatment or punishment.

14. A party or witness in any proceedings who does not understand or speak the language in which the proceedings are conducted has the right to the assistance of an interpreter.

15(1). Every individual is equal before and under the law and has the right to the equal protection and equal benefit of the law without discrimination and, in particular, without discrimination based on race, national or ethnic origin, colour, religion, sex, age or mental or physical disability.

\section{THE «SAFE THIRD COUNTRY»PROVISIONS}

S. 46.01(1) provides that a person who claims to be a Convention Refugee is not eligible to have the claim determined by the Refugee Determination Division if:

«(b) [the person] came to Canada, directly or indirectly, from a country, other than a country of the person's nationality or, where the person has no country of nationality, the country of the person's habitual residence, that is a prescribed country under paragraph $114(1)(s)$.»

It is only when the SIO deems a person eligible that her claim will actually be heard by the Refugee Division. Thus, the major obstacle to a determination of the merits of a claim is this initial decision by the Senior Immigration Officer. In this sense, the safe third country provisions (as well as 
the prior criminal record ones) constitute screening devices geared to reducing the number of claims actually heard by the Refugee Division. ${ }^{20}$

The only exception to s. 46.01(1)(b) is contained in s. 46.01(3)(a) which provides that a person who is in a country solely for the purposes of joining a «connecting flight» to Canada shall not be considered as coming to Canada from that country. The combined effect of these provisions is as follows: if a Convention refugee arrives in Canada after spending one week in Chicago, he will not be able to have his claim determined in Canada but will be sent by the SIO back to the United States ${ }^{21}$ unless she is satisfied ${ }^{22}$ that the one week stay was for the purposes of a connecting flight.

It is clear that an individual expelled under the safe third country provisions is not being returned to his home country. Instead, he is being sent to face a refugee determination hearing in his first country of arrival, as long as the Canadian government prescribes that country to be «safe» under the definition found in section 114(1)(s). Under s. 114(1)(s), the Minister classifies countries as «safe» using the list of criteria found in s. 114(8). The criteria are as follows: (1) is the country a signatory to the 1951 United Nations Convention Relating to the Status of Refugees ${ }^{23}$; (2) are its policies and practices in compliance with Article 33 of the Convention, which provides that no claimant is to be sent to a place where her security of the person shall be threatened; and (3) does it possess a progressive human rights record? These, however, are guidelines and not mandatory requirements. ${ }^{24}$ Thus, a country can fail to satisfy these criteria yet still be included on the list.

20. In the government's view, these legislative amendments will allow the most meritorious claims to proceed as quickly as possible: Refugee Affairs Division, Refugee Perspectives, 1987-88, (Ottawa: The Division, 1988), p. 36.

21. The U.S.A. is a safe country under s. 114(1)(s). See note 76.

22. The burden of proving eligibility rests on the applicant: S. 45(4) of the Act to Amend the Immigration Act. The Immigration Act contains another provision, section 8(1), which reads as follows: «Where a person seeks to come into Canada, the burden of proving that he has a right to come into Canada or that his admission would not be contrary to this Act or the regulations rests on him.»

23. 189 U.N.T.S. 137 (No. 2545) [hereafter the Geneva Convention or Convention.]

24. S. 114(8): «The Governor in Council shall take the following factors into account...». Within the context of legislative drafting, «shall» can be considered to be a permissive term, unlike «will», «is to», or «must». 
The concept of returning a claimant to a «safe» place was enacted to promote international co-operation in the area of refugee matters. While it is true that the preamble to the Geneva Convention ${ }^{25}$ encourages a co-ordinated interstate response to the influx of refugees, sending someone to a third country might amount to the first step in returning that person to a dangerous place, namely her home country. Bill C-86 does not preclude this possibility since it does not require the Minister to receive assurances from the safe third country that it will accord the expelled claimant a fair refugee hearing or even a hearing at all. This could violate Article 33 of the Geneva Convention, to which Canada is itself a signatory. ${ }^{26}$

\section{SECTION 12}

As held in the Motor Vehicle Reference ${ }^{27}$, section 12 is illustrative of section 7 since «cruel and unusual treatment» is an example of a violation of life, liberty and security of the person. ${ }^{28}$ Thus, since a statutory instrument may not constitute cruel and unusual treatment yet still violate the liberty and security of a person, it is opportune to first determine whether Bill C-86 infringes s. 12.

This essay shall only discuss whether Bill C-86 occasions cruel and unusual «treatment», not «punishment». The reason for this is clear. The caselaw applying s. 12 to the immigration context has held that a deportation simply does not amount to «punishment». ${ }^{29}$ Nevertheless, both the Supreme Court in Chiarelli v. M.E.I. ${ }^{30}$ and the Federal Court of Appeal in Canepa v. M.E.I. ${ }^{31}$ have indicated that a deportation or expulsion may come within the scope of cruel or unusual «treatment».

25. The Preamble reads as follows: «Considering that the grant of asylum may place unduly heavy burdens on certain countries, and that a satisfactory solution of a problem of which the United Nations has recognized the scope and nature cannot therefore be achieved without international co-operation.»

26. The Convention's requirements are listed as policy objectives in ss. 3 and 53 of the Act.

27. [1985] 2 S.C.R. 486 at 502.

28. The major difference being that cruel or unusual treatment can never comport with fundamental justice unlike violations of life, liberty and security of the person.

29. Chiarelli v. M.E.I., [1992] 1 S.C.R. 711 at 735, per Sopinka J. [hereafter Chiarelli].

30. Id.

31. [1992] F.C.A., D. 1614-03. 
The crux of the matter involves the following question: how can sending someone back to face a refugee determination hearing in a safe third country constitute cruel and unusual treatment? A caveat must be drawn: since the Charter does not have extraterritorial application, it is the act taken by the government of Canada that must be cruel and unusual, not that of a foreign government. ${ }^{32}$

The jurisprudence on the constitutionality of Canada's extradition procedures indicates how s. 12 is to be applied to the actions of foreign governments on individuals benefitting from Charter protection. In $R$. v. Kindler $^{33}$, an individual convicted of murder in the United States escaped to Canada after having been sentenced to death by a Pennsylvania court. The Supreme Court of Canada held that it would not amount to cruel or unusual treatment to extradite him to face capital punishment. The test adopted by the majority of the court was that s. $12^{34}$ would be violated if extraditing someone would «shock the Canadian conscience». ${ }^{35}$ Extraditing Mr. Kindler was determined neither to «shock the Canadian conscience» nor «offend the Canadian sense of what is fair, right and just.» ${ }^{36}$

Under the Kindler test the Canadian conscience could be shocked by directly returning bona fide Convention refugees to face imprisonment, torture or death. ${ }^{37}$ At first blush, Bill C-86 seems to preclude such a situation since any claimant (if at all expelled) will only be returned to a «safe» country. However, a closer examination of the legislation reveals that it in fact significantly increases the risk that legitimate claimants will face just such a deleterious result.

As stipulated by section 114(7), the Minister is required to review the list of «safe» countries every two years and either add or remove countries at her discretion. It is here that a fundamental problem arises. Although the Minister

32. Schmidt v. The Queen et al. (1987), 39 D.L.R. (4th) 18 at 24-5 (S.C.C.).

33. 67 C.C.C. (3d) 1 [hereafter Kindler].

34. And fundamental justice under s. 7.

35. Kindler, supra, note 33, at 9 (per McLachlin J., L'Heureux-Dubé J., and Gonthier J.)

36. Consult note 43.

37. Mattia v. Canada (M.E.I.) (1987), 25 Admin L.R. 80 (F.C.T.D.). 
is supposed to monitor the countries on the list, a country may becomes «unsafe» and a claimant sent back to that country before the Minister changes its status. Directly expelling a claimant to such a country could shock the Canadian conscience.

Given the volatile political climate in many countries, such a possibility is far from remote. In fact, it has already come before the courts. In Cheema ${ }^{38}$, a claimant was denied Convention Refugee status. A deportation order was issued against him. The claimant then supplied evidence that the political conditions in his native Punjab had deteriorated from the time of his arrival to Canada to the date on which his claim was rejected. He argued that his application for Convention status should thus be reassessed. The Federal Court ruled that deporting the claimant violated his Charter rights since he was denied a hearing at which to present evidence of these «changing political conditions». The application of section 114 to the eligibility determination is equally heavyhanded, as the claimant is given no opportunity to present any evidence at all whether the country to which he is being directly sent by Canada is actually safe for him. Many third countries may be «safe» for certain classes of refugees yet not for others. ${ }^{39}$

Nor is the claimant given a chance to explain why he left that third country in the first place. The Supreme Court, in $R$. v. Goltz, underscored the fact that any characterization of treatment as cruel or unusual should begin «from the perspective of the person actually subjected to [that treatment]». ${ }^{40} \mathrm{By}$ precluding the articulation of this perspective, s. 46.01(1) violates Charter section 12 .

On another note, the «safe» country may have policies that deny the individual a fair refugee determination hearing. It would «offend the Canadian sense of what is right, fair or just» to send a claimant to a country without assurances that its officials will accord him a fair hearing before returning him

38. Cheema v. Canada (M.E.I.) (1991), 15 Imm. L.R. (2d) 117 (Fed. T.D.).

39. Consult Orantes-Hernandez v. Meese, 685 F. Supp. 1488 (D.C. California) [infra, note 72] as well as this essay's discussion of how Bill C-86 violates the life, liberty and security of refugee claimants.

40. [1991] 3 S.C.R. 485 at 505. 
to a potentially dangerous home country. Yet the Act does not require such assurances in order for a country to be deemed «safe». It should be noted that, in the time leading up to the enactment of Bill C-86, the Canadian government attempted to negotiate a «safe-haven» pact with U.S. authorities in order to ensure that any person denied a hearing in Canada and returned to the United States would be guaranteed a hearing by American officials. ${ }^{41}$ The negotiations fell through. Until such agreements are actually passed with every country placed on the list in section 114(1)(s), the safe third country provisions shall remain unconstitutional.

Although in Kindler the lack of any assurance that the fugitive would not receive the death penalty was not deemed to violate section 12 , the situation of Mr. Kindler is distinguishable from that of refugee claimants. In Kindler the Supreme Court emphasized that administering capital punishment to an individual convicted of murder after a fair trial was not per se cruel and unusual. In the case of the amended Immigration Act, it is difficult to see how our collective conscience would not be shocked by imposing the risk of severe punishment upon a refugee without having had the merits of her claim even discussed.

Given the quasi-penal ${ }^{42}$ consequences of the SIO's decision, an examination of the s. 12 jurisprudence in the criminal context is useful to help define the meaning of «shock the conscience» in immigration matters. In the domestic criminal context, treatment is cruel and unusual if it is so excessive as to outrage standards of decency. ${ }^{43}$ This test was first developed by Laskin

41. «Lack of U.S. safe-haven accord dulls teeth of new immigration law», Peggy Curran of the Montreal Gazette (January 21, 1993).

42. Decisions are to be characterized by their effects and consequences. The results of the SIO's decision are serious: it is not uncommon for denied claimants to be summarily executed upon their forced return to their home countries. In fact, in recent years Canada has returned several claimants to Iran to face death. This decision to return has consequences more serious than any criminal decision in Canada. If we are willing to attribute «penal» status to a Provincial Court Judge's determinations of fraud, assault and shoplifting, why should we hesitate to ascribe (in the least) the same status to the SIO's decision?

43. Cruel and unusual treatment is determined by different approaches depending on the particular context in question. It appears that there is no definitive test as to what constitutes cruel and unusual treatment, just a variety of mutually inclusive standards to be used with an eye to the specific facts involved. 
C.J.C. in Miller and Cockriell ${ }^{44}$ and has been applied within the context of section 12 by the Supreme Court in Goltz. ${ }^{45}$ In Goltz, Gonthier J. adopted the view that, in order to be «outrageous», there must be a gross disproportion between the treatment and what would have been appropriate in the circumstances. ${ }^{46}$ Clearly, there is no proportionality between failing to satisfy an administrative requirement unrelated to the actual merits of one's refugee claim (coming to Canada from a «safe third country») and expulsion from Canada, given that this expulsion could result in torture or even death.

This discussion of Bill C-86 uncovers a broader issue: within Charter jurisprudence there has been little discussion of the interplay between s. 12 and procedural guarantees of due process. A persuasive argument can be made that since s. 12 prohibits cruel and unusual treatment per se, it should not matter whether an individual has actually received due process before being sent to face such treatment. ${ }^{47}$ Thus, whether Mr. Kindler had a fair trial or not should be simply irrelevant; what is relevant is that it did not violate section 12 to send someone to face the death penalty at the hands of a foreign state. ${ }^{48}$ To this end, the Ministry of Immigration could contend that, given Kindler as a precedent, there is no way that s. 46.01(1) violates s. 12. The reply to this is that a closer reading of Kindler reveals that the Supreme Court did not separate s. 12 from due process.

44. Cited in R. v. Smith, [1987] 1 S.C.R. 1045 at 1072, per Lamer J.

45. Goltz, supra, note 40, at 499. This case involved the decision that a penalty of seven days' imprisonment and a fine of $\$ 300.00$ for a first conviction for driving while prohibited did not infringe s. 12.

46. Id. $\quad$.

47. A logical extension of the argument would be that procedural concerns ought only to be discussed under s. 7.

48. In making such an argument, the Ministry would have to circumvent the conclusion of La Forest J. in Kindler, supra, note 33, in which he held at 4 that «...certain punishments imposed following surrender, such as torture, would be so outrageous to the values of the Canadian community that surrender would be unacceptable.» La Forest J. therefore distinguishes capital punishment from torture. Although the logic of such a distinction could be perceived as tenuous, it is found in the jurisprudence of the Supreme Court. Thus, even on a direct application of Kindler, sending an individual to face torture, even if twiceremoved from Canada, would shock our collective conscience. 
In fact, if the determinative test for a s. 12 violation is the Kindler «shock the conscience» test, it seems that the Supreme Court has in fact created room for procedural concerns within section 12. For example, if two claimants flee the same dangerous home country and Canadian authorities return one after a thorough hearing reveals him to be a dangerous international criminal, this may not «shock the conscience». Yet, turning away the second claimant without any due process determination as to his bona fides could «shock the conscience» even though both individuals would be subjected to the same treatment at the hands of the state officials of the home country. ${ }^{49}$ Bill C-86 thus violates s. 12 since its inadequacy of procedural guarantees heightens the risk that cruel and unusual treatment shall be inflicted on a bona fide claimant.

Moreover, the arguments related to the lack of extraterritorial application of the Charter are shortsighted since they run counter to the spirit of the Charter itself. ${ }^{50}$ The Charter's purpose is to protect individuals from the effects of governmental intervention. ${ }^{51}$ This perspective was superimposed upon the extradition context in Cory J.'s dissenting judgement in Kindler [italics are mine]:

«The manner in which a foreign state deals with the fugitive upon surrender may, in some situations, violate the Charter. When such a likelihood arises, Canada must accept responsibility for the ultimate consequence of the extradition. To argue that the Charter protection against cruel and unusual punishment does not apply because the punishment is inflicted by [another] state is an indefensible abdication of moral responsibility. ${ }^{52}$

49. The extent to which we extend s. 12 protection to refugee claimants in Canada is a difficult issue for, if the protection is of a blanket nature, it could preclude Canadian authorities from ever sending any claimant (no matter how unmeritorious) to any dangerous place. Would this be too onerous for our immigration infrastructure? Perhaps. Yet, on the other hand, the problem with including procedural guarantees in $\mathrm{s} .12$ is that the scope of the protection against cruel and unusual treatment could be watered down since the door is opened to such treatment being permissible under certain circumstances.

50. First discussed in Hunter v. Southam Inc., [1984] 2 S.C.R. 145.

51. $\quad$ R. v. Big M Drug Mart, [1985] 1 S.C.R. 295.

52. $\quad$ Kindler, supra, note 33, at 6. 
A question arises as to whether giving the Charter extraterritorial application imposes Canadian values on other countries. This concern has animated the decisions of the Supreme Court in extradition matters. In Canada v. Schmidt, La Forest J. emphasized that the «judicial process in a foreign country [cannot] be subjected to finicky evaluations against the rules governing the legal process in this country [Canada]». ${ }^{53}$ It was held that Charter rights are not universal, but relative to the Canadian context. For the most part, political concerns such as promoting international comity lie at the heart of this interpretative approach.

However, the Charter could retain extraterritorial application when it is called upon to uphold the one set of human rights that are truly universal: those enunciated in the various United Nations Conventions. Every refugee claimant has the right under Article 32 of the Geneva Convention to be expelled to the home country only with due process of the law. ${ }^{54}$ Although it is clear that international covenants are not legally binding in Canada, Dickson C.J.C. held in Oakes that those international covenants to which Canada is a signatory help define the scope of Charter rights. ${ }^{55}$ In a subsequent decision, Slaight Communications v. Davidson, the Supreme Court held that Canada's international human rights obligations should inform the interpretation of Charter rights. ${ }^{56}$ This caselaw supports the argument that the Geneva Convention's guarantees could be enforced through the Charter. We cannot lose sight of the fact that, if there are any individuals who are needy of a «large and liberal» interpretation of their Canadian constitutional rights, it is those who do not have any rights at all in their home country.

There is another way in which the safe third country provisions might inflict cruel and unusual treatment on a refugee claimant. In many cases a claimant, even if he has the intention of making a new home in Canada, will be unable to obtain a ticket to Canada from his home country. For example, let us take the case of East European refugees or those fleeing the disintegration of the former Yugoslavia. Due to financial or transportation limitations, a claimant 
Canada's new Immigration Act :

might only be able to take a train to Austria even though he has family or friends in Canada and wants to settle here. If he purchases a ticket to Canada in Vienna, he will be unable to have his claim determined in Canada since his original place of entry was Austria, a «safe» country. Moreover, given the fact that «connecting flight» is not defined in the Act, the Senior Immigration Officer will likely use a «common-sense» definition of the term which does not include tickets bought in a foreign country several weeks after the initial date of arrival. ${ }^{57}$ If s. 12 is given a broad reading, it could deem it to be cruel or unusual to force a claimant to have her claim adjudged in the first safe country in which she arrives, this often simply being the result of geography and airplane schedules. ${ }^{58}$ It must be remembered that refugees are seeking more than just temporary asylum, yet a permanent place where they can build a new life. The «co-ordinated interstate response» policy should not be pushed to the point that it infringes the principle of human dignity which lies at the heart of section $12 .{ }^{59}$

Yet another scenario demonstrates the unconstitutionality of Bill C-86. In March and August 1991 thousands of Albanian refugees sailed across the Adriatic Sea to seek asylum in Italy. The numbers were too large for the Italian authorities to handle at once and many claimants had to be forcibly returned without any refugee determination hearing. ${ }^{60}$ Although the Albanian government indicated that some of the refugees would be pardoned, Italian authorities knew that the subset of claimants who were completing military service (several hundred) would, upon their return, be charged by a military court with desertion. ${ }^{61}$ To this end, when there is a particular glut of refugees to one «safe» country, that country (such as was the case with Italy) might be forced to adopt

57. The constitutionality of the «connecting flight» provision could perhaps be preserved if the courts read in a definition of the term broad enough to cover situations such as this, where claimants need to spend time in third countries for transportation, financial or other related considerations. This approach is discussed in section D, infra.

58. In Akthar v. Canada (M.E.I.) (1991), 14 Imm. L. R. (2d) 39 at 43, Hugessen J.A. of the Federal Court of Appeal held that, within the immigration context, he «...might even be prepared to concede that unreasonable restrictions touching the very fundamentals of human existence might be found to constitute cruel or unusual treatment.»

59. Naturally, whether or not «human dignity» covers a choice as to where to immigrate or a right to family unification is a question for the courts to determine. As the number of involuntary migrants increases, this particular issue shall increase in importance.

60. «Repatriated Albanians 'tricked' by Italy», Globe \& Mail, August 19, 1991, p. A1.

61. Id. 
a stricter admission policy than normal and turn away bona fide claimants such as the Albanians in question. ${ }^{62}$ Under the provisions of Bill C-86, any claimant in such a situation, if he were to have left Italy for Canada, would be promptly returned to Italy by the Senior Immigration Officer even if she knew of the situation in Italy. At that point, any such claimants would likely be returned to Albania (a country known for its human rights abuses). ${ }^{63}$ The fact that there is no discretion with regards to turning back a claimant opens the door to the possibility that cruel and unusual punishment might ensue from the application of the Act.

In sum, until the international community develops standardized and fair refugee determination policies ${ }^{64}$ that will be applied consistently among all safe third countries, the possible risks of refusing someone a merit-based hearing in Canada could be serious enough to violate section 12 .

\section{SECTION 7}

The scope of «life, liberty and security of the person» is much broader than «cruel and unusual punishment». Even if the impugned sections of the Immigration Act do not violate section 12, they may still infringe section $7 .^{65}$

The threshold question is whether the expulsion violates the claimant's «life, liberty and security of the person». In Singh, Wilson J. held that s. 7 «...must encompass freedom from the threat of physical punishment or suffering

62. Italy deported these claimants despite an appeal from the United Nations High Commissioner for Refugees to accept the influx: Globe \& Mail, March 9, 1991, p. A10.

63. The International Helsinki Foundation affirms that, at the time of the influx to Italy, about 200 political prisoners were incarcerated in Albanian jails, their only «crime» being to try to emigrate.

64. This does not necessarily mean the most favourable procedures imaginable, yet simply fair due process as per international standards.

65. It is important to bear in mind that ss. 7 and 12 are interconnected and that there is a certain element of overlap between them. Thus, the contingencies discussed in the preceding section can also be used as evidence of a potential section 7 violation. For purposes of brevity they shall not be repeated here. 
as well as freedom from such punishment itself.» ${ }^{66}$ Therefore, any decision that exposes an individual to such a risk infringes his security of the person. The SIO's decision could expose the claimant to the type of risk envisioned in Singh.

Moreover, in Aktharv. Canada (M.E.I.) Hugessen J.A. held that merely being placed in the refugee determination process puts in issue the claimant's life, liberty and security of the person.$^{67}$ Canadian courts have even held that state-imposed psychological trauma constitutes an infringement of s. $7 .^{68}$ This line of reasoning has its origins once again in Wilson J.'s judgment in Singh, in which she concluded that [italics are mine]:

«To deprive [a refugee] of the avenues open to him under the Act to escape from the fear of persecution must, at the least, impair his right to life, liberty and security of the person.» ${ }^{69}$

The geographic patterns of involuntary migration help illustrate how Bill C-86 violates the refugee claimant's right to life, liberty and security of the person. Fully one-third of all individuals arriving at Canada's borders through safe third countries pass through the United States. To this end, the «safe third country» turnaround provisions will mean that tens of thousands of claimants will be returned to American authorities. ${ }^{70}$ Passing through the U.S. is a transportation necessity for refugees arriving to Canada from Latin America. This is cause for concern since the United States has a record of unfair treatment of these refugees. American immigration practices related to Latin America have [1988] 1 S.C.R. 30 at 166, Wilson J. expanded her position and held that security of the person covers the right of an individual to make important decisions related to her person independently of state intervention. An immigrant's choice of migrating to a new home could qualify as such a decision.

67. Akthar, supra, note 58, at 43 .

68. Morgentaler, supra, note 66, at 45. Consult also R. v. Mills, [1986] 1 S.C.R. 863, per Lamer J. In Collin v. Lussier, [1983] 1 F.C. 218 at 239, Décary J. of the Federal Court Trial Division held that merely increasing a person's anxiety as to his state of health (based on the possibility that the individual's health would in fact be placed in jeopardy) was sufficient to trigger s. 7.

69. Singh, supra, note 6, [1985] 1 S.C.R. 117 at 260.

70. Of the 44,000 refugees presenting their claims in Canada in 1992, roughly 15,000 came via the United States. 
been found to be arbitrary and linked to the particular political or strategic relationship the «home» country has with Washington. ${ }^{71}$

Examples of this unfairness are found in the facts of Orantes-Hernandez v. Meese. ${ }^{72}$ In this case, the Federal District Court for California was presented with evidence attesting to U.S. immigration practices that flagrantly violate the terms of Article 33 of the Geneva Convention, to which the U.S. is a signatory. El Salvadorean refugee claimants were routinely denied determination hearings and were often coerced by U.S. authorities to sign «voluntary» deportation consent forms. Kenyon D.C.J. held that these claimants were entitled to the protection of Article 33 and declared their «voluntary» deportation forms to be void. Nevertheless, the effect of this decision has recently been diluted. In June 1993 the U.S. Supreme Court held in Sale v. Haitian Centers Council that the interception of Haitian 'boat people' (political as well as economic refugees) and their forced return to Haiti was constitutionally permissible. ${ }^{73}$ Stevens J. held that the government's actions ${ }^{74}$ contravened neither the Bill of Rights nor Article 33 since neither have extraterritorial effect. ${ }^{75}$ The Supreme Court's position is that Article 33 only applies to the domestic procedures by which the Attorney-General decides which claimants might remain in the U.S.A. Thus, if Canada is to return a claimant to the U.S.A., American officials are not bound by the terms of Article 33 until that person has already entered the U.S. refugee determination system. U.S. officials are then free to keep that claimant «in orbit»

71. Catherine Torlai, «La politique des Etats-Unis d'Amérique relative aux refugiés et à l'immigration: problèmes et solutions», in Dominique Turpin, ed. Immigrés et réfugiés dans les démocraties occidentales: défis et solutions, (Economica: Paris, 1989) p. 189 at 194 and 195. In effect, Convention refugees have been found to be treated differently depending solely on their national origin. For example, in 1983 the United States accepted $87 \%$ of Soviet and $44 \%$ of Romanian refugee claimants yet only $3 \%$ of El Salvadorean and $2 \%$ of Guatemalan claimants.

72. $\quad 685$ F. Supp. 1488 (D.C. California).

73. Sale v. Haitian Centers Council (1993), 125 L Ed 2d 128 (U.S.S.C.).

74. Passed through Executive Order 12807 which allows the U.S. Coast Guard to intercept vessels on the high seas transporting passengers from Haiti to the U.S. and return such persons to Haiti without first determining whether they might qualify as refugees.

75. Haitian Centers Council, supra, note 73, at 133. Stevens J. found that the actions of the U.S. Coast Guard violated the «spirit of Article 33» and even of U.S. immigration legislation. Nevertheless, neither applied to the Haitians in question since they were intercepted in international waters. Furthermore, the Bill of Rights will not apply to any refugee claimant illegally in the United States. 
or return him to the home country. Thus, given that it is politically improbable that Canada would ever declare the U.S. to be an «unsafe» third country ${ }^{76}$, the life and security of those refugees «passing through» the United States is especially threatened.

S. 46.01(1) cannot be deemed to infringe $s .7$ merely because it deprives a claimant of her security of the person. Section 7 will only be violated if the specific deprivation is not made in accordance with fundamental justice. As outlined by Lamer J. in the Motor Vehicles Reference, fundamental justice has both a substantive and a procedural aspect. ${ }^{77}$ It is difficult to conceive how the perfunctory decision of the Senior Immigration Officer as to whether an individual arrived from a «safe» third country for the purposes of a connecting flight satisfies the threshold of procedural fairness mandated by section 7 .

It is settled law that fundamental justice is to be contextually defined. ${ }^{78}$ In Singh it was concluded that the severity of the potential outcome should determine the extent of the procedural protection within the decision-making process. ${ }^{79}$ This case is of high precedental value due to the similarity of its facts to potential situations that shall likely emerge under Bill C-86.

In Singh, legislation disentitling a refugee claimant to a full oral hearing in an immigration re-determination proceeding was determined to be inoperative due to its violation of fundamental justice. Wilson J. concluded that, given the seriousness of the outcome of the decision, the claimant must be able to state his

76. Jack Shields, Parliamentary Secretary to the Minister of Employment and Immigration: «The United States I would consider a safe country under the refugee determination system. It has proven that in the past. It has been a very generous country in the past.», Hansard, 132:163 at 12507, June 22, 1992. Consult also Margaret Young, Canada's Refugee Status Determination System, Background Paper, Ottawa: Library of Parliament Research Branch, (Revised, September 1991) and Arthur C. Helton, Lawyers' Committee for Human Rights, «Brief to the Legislative Committee on Bill C-86», August 1992.

77. Motor Vehicles Reference, supra, note 27, at 487.

78. $\quad$ R. v. Beare, [1988] 2 S.C.R. 387; R. v. Lyons, [1987] 2 S.C.R. 309.

79. Singh, supra, note 6, 58 N.R. 1 at 62-3. This principle was echoed by Cory J. in The Queen v. Wholesale Travel, [1991] 3 S.C.R. 154 at 226: «Context is relevant both with respect to the delineation of the meaning and scope of Charter rights, as well as to the determination of the balance to be struck between individual rights and the interests of society.» 
case as well as know the case he has to meet. ${ }^{80}$ The effects of the Senior Immigration Officer's decision are just as far-ranging as those of the Immigration Board in Singh. At best, the claimant will be exposed to a refugee determination hearing in a country in which she has expressly chosen not to settle. At worst, the claimant could be eventually returned to face punishment or death in the home country without any hearing at all. Given the gravity of the consequences, the eligibility determination by the Senior Immigration Officer should be encircled with procedural safeguards to at least allow the claimant to be told the case against him and to be given a fair opportunity to respond. ${ }^{81}$ However, the Act does not provide for a hearing, whether oral or written. ${ }^{82} \mathrm{~A}$ section 7 violation is thus triggered.

As explained earlier, the claimant is unable to present any evidence as to why the «safe third country» might not be safe for him. In Singh, it was held that oral hearings are mandatory when there is a serious issue of credibility or when the determination will only be effective if the subject of the determination can present «his side of the story». In the case of a refugee claimant, the «safeness» of the third country is a serious issues of credibility.

Furthermore, in what will likely be one of the most important determinations in the claimant's life, no provision is made for any right to counsel. Even though the onus of proving that one's claim is eligible to be determined in Canada rests with the applicant ${ }^{83}$, no allowance is made for legal advice to help discharge the burden of proof. In Howard v. Stony Mountain, the Federal Court held that the right to counsel emerges when a person is in a situation where the consequences of a decision are severe and she might not have sufficient «aptitude» to understand and present her case. ${ }^{84}$ Such a situation can easily arise in the refugee determination process.

80. Singh, supra, note 6, 58 N.R. 1 at 64.

81. Singh, supra, note 6.

82. The officer has the power to look at the arrivant's travel documents, determine whether she came from a «safe third country», decide if the stop was for the purposes of a connecting flight, and immediately order her back.

83. Section 45(4) of the Immigration Act.

84. [1984] 2 F.C. 642 at 663. 
However, any argument that Bill C-86's failure to provide a right to counsel violates s. 7 must, in order to be successful, circumvent the March 1993 Supreme Court decision in Dehghani v. Canada (M.E.I.). ${ }^{85}$ In Dehghani, Iacobucci J. held that fundamental justice does not require that a lawyer be present at a preliminary meeting at which a claimant's status as a refugee is to be determined. Nevertheless, Iacobucci J. was careful to point out that the absence of a lawyer was only permissible because the meeting in question was nothing more than a «routine information gathering» session and not an actual hearing. The Dehghani situation can therefore be distinguished from situations that would arise under Bill C-86 in which claimants would be without counsel at hearings during which the SIO would have the power to expel them from Canada. In fact, at least one commentator on the Dehghani decision has noted that, under Bill C-86, the absence of legal counsel at the «front-line» hearings could violate s. 7 given the greater magnitude of these hearings than those at issue in Dehghani. ${ }^{86}$

Even if the Charter may not require the provision of a lawyer at the refugee determination hearing, it does mandate the presence of an interpreter. Despite the fact that many claimants simply do not speak English ${ }^{87}$, the Act does not require the services of an interpreter when these claimants first meet with the SIO. The entire expulsion process could take place without the claimant comprehending any of the procedures nor the Immigration Officer being able to understand anything the claimant has to say. Along with infringing section 7 of the Charter, this specifically denies the section 14 right to an interpreter in any «proceedings». The eligibility decision of the Senior Immigration Officer certainly bears serious enough consequences on the claimant to qualify as a «proceeding» under the Charter. ${ }^{88}$

85. (1993), 39 A.C.W.S. (3d) 501 (S.C.C.).

86. Richard Boivin, «La Charte permet l'examen secondaire d'un immigrant», The National, August/September 1993, p. 40.

87. Or French. Xie v. Canada (M.E.I.) (1990), 10 Imm.L.R.(2d) 284 at 107.

88. Such was the position of the Federal Court of Canada in Brar v. Canada et al. (1989), 30 F.T.R. 284 at 300 . It was held that immigration decisions fall under the rubric of s. 14 «proceedings». 
Furthermore, under Bill C-86, the claimant will not have notice of the exact case that shall be tendered by the SIO. In its 1992 decision in Lakeside Hutterite Colony v. Hofer, the Supreme Court of Canada held that notice is a «most basic requirement» of fundamental justice. ${ }^{89}$ On a related note, the claimant is not entitled to discover the Minister's case. In Singh, Wilson J. held that «...as a matter of fundamental justice, a refugee claimant would be entitled to discovery of the Minister's case». ${ }^{90}$ With Hofer and Singh as precedents, the lack of notice and discovery contribute to a s. 7 violation.

Moreover, there is no sensitivity to the fact that a claimant may simply be unaware of the conditions precedent for entry into Canada. The Ministry assumes claimants to have knowledge of the requirements for admission into the Canadian refugee determination process. This assumption seems unreasonable given the fact that the claimant will be far removed from Canadian public sources before choosing to come here. ${ }^{91}$ Although on its own the effects of this assumption might not be sufficient to infringe s. 7, they serve as evidence that, when coupled with the lack of counsel, interpreter, discovery and hearing, establish a Charter violation.

89. [1992] 3 S.C.R. 165 at 195, per Gonthier J. [hereafter Hofer]. The main purpose of the notice requirement is to ensure that the subject of the administrative decision can prepare to defend himself or herself as well as better contribute to the discussion.

90. $\quad 58$ N.R. 1 at 65

91. Whether refugee claimants should be assumed to have knowledge of the Canadian statutory provisions is a contentious debate. On one side of the debate are those who maintain that, since ignorance of the law is no defence to a criminal charge, why should it operate within the immigration context? Such was the reasoning of Décary J. in Metodieva v. Canada (M.E.I.), (1991, F.C.J. No. 629 at 9). This position, however, ignores the fact that a refugee claimant will have had far less access to the public record than any Canadian citizen charged with a criminal offence. Perhaps a more straightforward position on this issue is that taken by Vice-Chair Townshend of the Immigration Appeal Board in Crawford, infra, note 112, at 20:

«This may sometimes be a harsh responsibility to place on a lay person, particularly someone in a faraway foreign land. But in my view to derogate from that principle...is not an approach which commends itself to me either in logic, fairness or practicality.» 
Canada's new Immigration Act :

There is no opportunity to appeal the decision of the Senior Immigration Officer. ${ }^{92}$ Appeals form a key part of fundamental justice in so far as they enable decisions to be reviewed and new evidence to be adduced. In the decision of the Supreme Court in Chiarelli v. M.E.I., certain sections of the Immigration Act authorizing a deportation were determined to be constitutionally valid. ${ }^{93}$ Nevertheless, throughout the entire expulsion process, Mr. Chiarelli was statutorily entitled to numerous discretionary rights to appeal the decision of the Officer. These appeal guarantees were relevant to the constitutionality of the deportation provision. The absence of any such right (even a discretionary one) in Bill C-86 amounts to a denial of fundamental justice to refugee claimants. It also contravenes Article 16 of the Geneva Convention, which provides that a refugee shall have free access to the courts of law on the territory of all signatory states. $^{94}$

In Chiarelli, Sopinka J. held that «...the Court must look to the principles and policies underlying immigration law in determining the scope of fundamental justice. ${ }^{95} \mathrm{He}$ went on to add that the most fundamental principle of immigration law is that non-citizens do not have an «unqualified right» to enter

92. This seems to be a deliberate omission, since the Immigration Act allows claimants to appeal the decisions of the Convention Refugee Determination Division, yet not the initial decision of the Senior Immigration Officer that determines whether the claimant can address the Division at all.

Aside from a judicial review application, the only avenue open to a claimant is to use section 10(c) of the Charter to file a writ of habeas corpus in the court system, which is practically impossible given the fact that the claimant shall likely be detained in an airport (or a border crossing) and will probably have no understanding of the intricacies of the Canadian legal system. The main drawback with a judicial review application is that it requires leave of the court. Researchers have found that, in so far as the Federal Court of Appeal is concerned, there is a great deal of arbitrariness with regard to which applicants are given leave. There are wide variations from judge to judge: I. Greene \& P. Shaffer, «Leave to Appeal and Leave to Commence Judicial Review in Canada's Refugee Determination System: Is the Process Fair?» (1992), 4 Int'l. J. Ref. L. 71.

93. [1992] 1 S.C.R. 711. This case involved the expulsion of a permanent resident applicant to Italy (his home country) for the reason that he had been convicted of violent crimes in Canada. The deportation occured after his prison sentence in Canada had been served.

94. It is unclear whether «free access» includes access to the same courts Canadians may have access to. There could be a conflict if «free access» is taken in its literal sense since this means that refugee claimants could acquire access to courts normally inaccessible to Canadians.

95. Chiarelli, supra, note 93, at 733. 
or remain in the country. ${ }^{96}$ Nevertheless, the Immigration Act must not qualify this «right» by means not consonant with fundamental justice. In effect, Sopinka J.'s comments deny the fact that there is an even more basic principle animating immigration policy: no-one shall be sent back to a dangerous place without the benefit of a fairly conducted merit-based hearing. It is United Nations policy that no request for asylum be denied on the simple reason that the applicant could have requested protection in another nation. ${ }^{97} \mathrm{Bill} \mathrm{C}-86$ contravenes these principles as well as the section 7 and 14 rights of refugee claimants.

\section{SECTION 15}

Not every distinction infringes the equality provisions of the Charter. The appropriate test to determine which distinctions do violate section 15 is set out in Andrews v. Law Society of British Columbia ${ }^{98}$. There are two steps. The distinction must have a differential impact that results in a denial of equal benefit of or equal treatment before or under the law. Secondly, the distinction must involve a prohibited ground of discrimination. ${ }^{99}$ There are two types of prohibited grounds: those enumerated in section 15 and those analogous to these enumerated grounds. A thread between these two categories is that they frequently cover groups that have faced historical or structural disadvantage which has, in turn, rendered them «discrete and insular minorities». ${ }^{100}$

The safe third country provisions create a distinction on the basis of national origin: between refugees from countries with direct access to Canada and those without. Members of the latter group (unless they fit into the connecting flight exception) are denied the protection the Immigration Act accords refugee claimants directly arriving to Canada.

96. Id. See also Dehghani, supra, note 85.

97. Conclusion on the International Protection of Refugees Adopted by the Executive Committee of the U.N.H.C.R., Programme no. 15, 1979.

98. [1989] 1 S.C.R. 143.

99. Whatever intent or motive the government may have had in enacting the legislation is irrelevant since, given the decision of the Supreme Court in O'Malley v. Simpson-Sears, [1985] 2 S.C.R. 536 at 547, one does not need to find a discriminatory intent in order to prove discrimination.

100. Andrews, supra, note 98, at 183; R. v. Turpin and Siddiqui, [1989] 1 S.C.R. 1296 at 1332. 
Canada's new Immigration Act :

Since this distinction involves an enumerated ground, a prima facie s. 15 violation is established. ${ }^{101}$ Nevertheless, this violation is further consolidated if it is determined that the group receiving the differential treatment constitutes a discrete and insular minority. ${ }^{102}$ In fact, this was a requirement under the original Andrews test. The geography of refugee migration indicates that refugee-nationals of countries not directly linked to Canada are disproportionately most needy of securing asylum in Canada. ${ }^{103}$ To this end, the category of persons differentially affected by the safe third country provision constitutes an a priori disadvantaged group.

Nevertheless, even if this category does not qualify as a discrete and insular minority, recent Charter jurisprudence has held that an inability to demonstrate membership in such a minority is not necessarily a bar to establishing a s. 15 violation. For example, in $R$. v. Turpin and Siddiqui, Wilson $J$. held that proving the existence of a discrete and insular minority would merely be helpful (as an «analytical tool») to the success of the claim. ${ }^{104}$

101. Moreover, s. 46.01(1) also violates Article 3 of the Geneva Convention, which stipulates that «...the provisions of this Convention [be applied] without discrimination as to country of origin.» Although infringing an international covenant is not determinative of a Charter violation, it is evidence leading to such an end.

102. In response to the s. 15 challenge, the Ministry could suggest that there is simply no discrimination because claimants from countries not directly linked to Canada can always present a «normal» immigration claim. It is true that, should the claimant have advance knowledge about the safe third country provision, she can apply for immigration status in Canada instead of refugee status once she arrives in the safe third country. However, what if she does not have this knowledge, arrives in Canada and pleads refugee status? Her application would be denied and she would be returned. At that point she cannot switch categories to «normal immigration candidate». In effect, two parallel systems are created: one for immigrants, one for refugees: s. 57(1) of the Immigration Act. Moreover, even if switching were possible, a refugee would likely be disadvantaged by the standards for a successful immigration application which focus on wealth, education and linguistic ability, not the threat of persecution.

103. For example, as discussed earlier, the Latin American refugees who basically have no choice but to pass through the United States en route to Canada. Doing so opens them up to the unfair practices related to Latin American refugees scholars such as Torlai have found to be present within American refugee policy: consult note 71 et seq.

104. [1989] 1 S.C.R. 1296 at 1333. Nevertheless, in this case Wilson J. held that «...it would be stretching the imagination to characterize persons accused of one of the crimes listed in $\mathrm{s}$. 427 of the Criminal Code in all the provinces except Alberta as members of a 'discrete and insular minority'», at 1333. To this end, there are still clear limits to which groups can launch 
Furthermore, in its 1990 decision in $R$. v. Hess, the Supreme Court held that s. 15 could be offended if a statute discriminated against men, clearly not a «discrete and insular minority». ${ }^{105}$ This lessening of the requirements of the original Andrews test should make it easier for those not members of discrete and insular minorities to launch s. 15 claims, especially when the distinction involves an enumerated ground. ${ }^{106}$ For his part, Peter Hogg maintains that, in order to establish a s. 15 violation, it need only be shown that a law imposes a disadvantage upon a person by reason of a named or analogous characteristic. ${ }^{107}$

\section{THE «PRIOR CRIMINAL RECORD» PROVISIONS}

Bill C-86 provides that a person is not eligible to have the claim heard by the Refugee Division if he has been determined by an adjudicator to be a person described in s. 19(1)(c.1)(i) and if the Minister believes he constitutes a danger to the Canadian public. S. 19(1)(c.1)(i) reads as follows:

«No person shall be granted admission who is a member of any of the following classes:

(c.1) Persons who there are reasonable grounds to believe

(i) have been convicted outside Canada of an offence that, if committed in Canada, would constitute an offence that may be punishable under any Act of Parliament by a maximum term of imprisonment of ten years or more.»

Unlike the case with the safe third country provisions, claimants are not returned to a «safe place» to face a hearing, but are instead sent directly back to their home countries, no matter how heinous the potential treatment they may receive there. As with s. 46.01(1), these provisions are screening filters: instead

a claim under s. 15 .

105.
106. Not always. Although the Turpin approach to s. 15 was approved by Lamer J. in $R$. v. Généreux, [1992] 1 S.C.R. 259 at 275 and 311, in the most recent decision of the Supreme Court on the matter -- Haig v. Canada (Chief Electoral Officer), [1993] 2 S.C.R. 995 at 1043 -- L'Heureux-Dubé J. held that the failure of the complainant to prove membership in a «discrete and insular minority» was detrimental to his claim.

107. P.W. Hogg, Constitutional Law of Canada, 1992, Third Edition (Toronto: Carswell), para. $52.7(\mathrm{~g})$. 
Canada's new Immigration Act :

of having one's prior criminal record go to the substance of one's actual claim, it affects one's admissibility in the entire process. ${ }^{108}$

This section is very similar to s. 19(1)(c) of the former Immigration Act which denied permanent residence to individuals claiming immigration status (generally persons from «safe» countries) who have a prior conviction. Given that the present «prior criminal record» provisions affecting immigration claimants and refugees are placed in the same section of the Act and encompass the same wording, the intent of the legislature appears to be that the methodology used to apply the former s. 19(1)(c) is to be used in the application of 19(1)(c.1)(i). If this is the case, the effect of 19(1)(c.1) might constitute cruel and unusual punishment or, at least, violate section 7 .

In applying subsection 1(c), courts had developed an equivalency test to evaluate whether a foreign criminal offence should be recognized in Canada. ${ }^{109}$ Judicial review also provided for a broad «fairness» duty in this area so that any claimant could have an opportunity to make representations. Nevertheless, despite the existence of these safeguards, immigration authorities have, in recent years, denied permanent residence applications on the basis that the applicant had impersonated a chauffeur in Hong Kong in $1965^{110}$, that the applicant had stolen the equivalent of $\$ 2.50$ worth of goods ${ }^{111}$, and that the applicant had killed an animal in 1959 with the intent to steal the carcass. ${ }^{112}$ These examples indicate that the Ministry has a low standard of who «constitutes a danger to the public

108. These provisions work in tandem with many others in the Immigration Act designed to reduce the numbers of «international criminals» granted immigration status in Canada. This appears to be a clear priority of the government. In matters of «normal» immigration, s. 19(1)(c.2) allows the SIO to expel any claimant it is reasonably believed was a member of any organization that engaged in a pattern of criminal activity. Section 19(1)(c.1)(ii) is even more sweeping: it allows the SIO to expel a claimant who it is reasonably believed has committed outside Canada an offence recognized in Canada. Since these two provisions do not apply to refugees, a discussion of their constitutionality falls outside the scope of this essay. Nevertheless, this is an issue that should be addressed. However, this topic, just like the constitutionality of the provisions affecting refugee claimants, has so far attracted little academic attention.

109. Hill v. Canada (Minister of Employment \& Immigration) (1987), 1 Imm.L.R. (2d) 1.

110. Ong v. Canada (1987), 3 Imm.L.R. (2d) 119.

111. Wong v. Canada (1989), 8 Imm.L.R. (2d) 16.

112. Crawford v. Minister of Employment and Immigration (1987), 3 Imm.L.R.(2d) 12. 
in Canada». In fact, it appears that once a conviction of any sort is proven, the Minister is satisfied that the claimant constitutes a «danger».

Nevertheless, the identically worded prior criminal record exclusionary provision affects refugee claimants in a much different way than it does immigration claimants. The situation of a refugee is much more desperate than a permanent residence applicant from a safe country since the legal systems of «unsafe» nations are often highly arbitrary. To this end, it is much more tenuous to rely upon convictions from such states. Thus, the judicial equivalency test used in permanent residence applications should certainly not be applied in the context of the eligibility of a refugee. The present equivalency test has two components: (1) a comparison of the precise wording of each statute to determine the essential ingredients of the respective offences; (2) the examination of the evidence before the adjudicator to ascertain whether that evidence is sufficient to establish that the essential ingredients of the offence in Canada had been proven.

Although this test may serve the limited purpose of assessing claims from «safe» countries, its application in the context of refugee claimants will not be sufficient to allow section 19(1)(c.1)(i) to satisfy section 7. This test does not evaluate whether the police actions and judicial procedures in the foreign country conform at all to Canadian norms. No attention is paid to the origins of the evidence used to satisfy the second branch of the equivalency test.

There is thus no requirement that the conviction, in order to be relied upon, must have been arrived at in a manner that comports with (or is even loosely similar to) the Canadian understanding of fundamental justice. No one $^{113}$ is mandated to ask whether the initial determination of guilt was made in a fair trial, with right to counsel and the right to cross-examination of the accusers. In this sense, a substantive decision regarding the fate of a refugee will be made in Canada based on the result of a trial that could very well have violated every right the Charter, common law or international criminal

113. On another note, Bill C-86 does not indicate how the adjudicator is to be selected, to whom she is to be accountable, nor whether the SIO qualifies as one. 
procedures give an accused. This even raises the spectre of a s. 12 violation. ${ }^{114}$ Furthermore, there is no extraterritorial issue since the prior acts of the home country government (in having convicted the claimant) might be the determining factors in a decision made by the Canadian government affecting the claimant while she is on Canadian soil.

On a related note, what does «convicted» actually mean? In the recent decision of the Federal Court of Appeal in M.E.I. v. Burgon, Linden J.A. held that the term «convicted» (as used in section 19(1)(c) of the former Act) means «found guilty» after a plea of guilty or otherwise. ${ }^{115}$ Such a definition does not recognize the fact that threats of torture or punishment on family members are regularly used in many countries to secure guilty pleas. Large numbers of refugees flee their home countries to escape such governmental heavyhandedness. Yet, when they arrive in Canada, they may be denied a refugee hearing precisely due to criminal records stemming from this same heavyhandedness. Instead of minimizing the damaging consequences a prior criminal record might have, Bill C-86 amplifies them.

Moreover, what about the situation of an individual who has used false documents to escape the home country and come to Canada? In the area of immigration claimants from «safe» countries, the Federal Court has adopted the position that the use of false documents indicates an intention to be subversive in the host country. ${ }^{116}$ Technically, it also constitutes fraud, this being an offence under the Criminal Code ${ }^{117}$. If the same standard is applied to refugee claimants, many persons will be turned back simply because the only way for them to actually leave the home country was through falsified documents.

The provisions of section 19(1)(c.1)(i) are not absolute. There is one important element of discretion. The officer or adjudicator can let individuals with a prior criminal record have their claims determined if he feels that they:

114. A persuasive argument can be made that relying on potentially trumped up foreign convictions violates the Canadian sense of what is «fair, right and just» as set out in Kindler. 115. (1991), 122 N.R. 228.

116. Re Shandi (1992), 17 Imm.L.R. (2d) 54 at 62.

117. R.S.C. 1985 , c. C-46, s. 380(1). 
«have satisfied the Governor in Council that they have rehabilitated themselves and that at least five years have elapsed since the expiration of any sentence imposed for the offence or since the commission of the act or omission, as the case may be.»

Nevertheless, the provision is silent on some critical issues. For example, the SIO appears to have complete discretion whether to solicit the Governor in Council's opinion as to whether someone is «rehabilitated». Secondly, there is no publication of any criteria on what «rehabilitated» actually means so claimants are denied the chance to effectively prepare for this evaluation. ${ }^{118}$ With Singh as a precedent, the combined effect of these inadequacies infringes section 7 .

The «prior criminal record» provisions affecting permanent residence claimants also contain a «five year waiting period and rehabilitation» exception to the general rule barring such claimants from Canada. Case-law in this area has held that the Governor in Council's decision in this matter must comport with the principles of fundamental justice, which mandate that he or she have available all the information necessary to make a rational and informed decision. ${ }^{119}$ This should include the oral evidence of the applicant provided at a hearing. Hopefully this standard will be read into s. 19(1)(c.1)(i) and its application to refugees. Yet, the overall procedure still remains inadequate if hearings are mandatory to settle the question of rehabilitation yet not to determine whether the prior criminal conviction was fairly obtained in the first place.

118. Furthermore, the Act does not allow for a «compassionate and humanitarian» appeal from the adjudicator's decision to deny refugee status due to a prior criminal record. S. 77(3) (S.C. 1991 c. I-2) provides such an appeal to family class/sponsorship permanent residence claimants whose applications are denied. The purpose of s. 77(3) is «..to relieve against the harshness and rigours of the letter of the law.»: Crawford, supra, note 112, at 21, per ViceChair Townshend. Absent such an appeal for denied refugee claimants, the Act is inconsistent with the pre-Charter decision of the Supreme Court in Jiminez-Perez v. Canada, in which it was held that immigration officials are under a duty to grant every applicant the opportunity to put forward the compassionate and humanitarian grounds in his or her case: [1984] 2 S.C.R. 565.

119. Simpson v. Minister of Employment and Immigration (1987), 3 Imm.L.R.(2d) 20; Tsang v. Canada (Minister of Employment and Immigration) Imm. App. Bd., Doc. No. 83-6276. 
Canada's new Immigration Act :

S. 19(1)(c.1)(i) also touches on the Charter section 11 right to a fair proceeding. Although s. 11 only applies to «persons charged with an offence», if the section is given a liberal interpretation so as to cover a claimant awaiting the quasi-penal ${ }^{120}$ decision of the SIO, the possibility that the Act violates s. 11 becomes apparent. ${ }^{121}$ More specifically, the «prior criminal record» provisions can be said to infringe the $11(\mathrm{~g})$ right not to be found «guilty» of any offence unless it was an «offence under Canadian law» or «criminal according to the general principles of law recognized by the community of nations.» ${ }^{122}$ If there are «procedural guarantees» within the terms «an offence under Canadian law» or «the general principles of law recognized by the community of nations», then rendering an unfavourable decision against a claimant in disregard of these procedural guarantees potentially violates section $11(\mathrm{~g})$. Similarly, section 11(d)

120. See note 42 .

121. Such an elasticity within s. 11 appears to have been in the minds of the drafters of the Charter. It certainly has existed in the minds of judges. In Paruch v. Nova Scotia Nurses Union (1991), 112 N.S.R. (2d) 100 at 108, Ryan L.J.S.C. allowed a complainant the use of s. 11(d) in an administrative law matter involving the alleged failure of a union to fulfil its duty of fair representation.

S. 11(d) mandates a «fair and public hearing» -- not just a fair trial -- leading to the conclusion that the $\mathrm{s}$. 11 protections can apply to quasi-criminal and even administrative law contexts. There is little case-law in this area, though, and the Supreme Court has not given a meaning to «charged with an offence». However, in Canada v. Schmidt, [1987] 1 S.C.R. 500 at 519 , La Forest J. held that he was of the view that any meaning given to «person charged with an offence» must be «constant throughout the section...one that harmonizes with the various paragraphs of the section.» Since there is jurisprudence that a person unfairly represented by her union is entitled to the use of s. 11(d) at a grievance hearing (and is thus a "person charged with an offence») there is no reason why all the provisions of s. 11 should not be made available to a refugee claimant.

Nevertheless, the case-law is not unanimous on this point. In Tyler v. MNR (1989), 89 D.T.C. 5044, it was held that s. 11 did not apply to the furnishing of tax information to the Ministry of National Revenue. Moreover, in Brar v. Canada, 30 F.T.R. 284 at 300, an intelligence/security review for refugee purposes was determined to fall under the ambit of s. 14 , yet not that of s. 11 .

122. A similar argument was rejected by the Federal Court of Appeal in Wong v. M.E.I. (1989), 97 N.R. 352 , yet no supporting reasons were given. Further, this case involved a claim for permanent residence, not refugee status, and is thus of limited precedental value vis-à-vis the discussion at hand. What is relevant, however, is that the F.C.A. felt that the claimant's conviction for having stolen $\$ 2.00$ worth of food from a Hong Kong supermarket constituted a constitutional ground to deny her permanent residence claim. Bill C-86 stipulates that a refugee in the same position as Ms. Wong would be expelled to her home country. 
mandates that every hearing must be «fair» and this certainly includes procedural guarantees. Public policy considerations require Canadian tribunals to adhere to strict fairness considerations with regards to the type of evidence that they can rely on. Determinations in the area of immigration matters with similar (or even more serious) effects to criminal determinations cannot be exempted from this norm.

These constitutional questions touch on important issues not only related to immigration matters, but also the response of the global community to crime more generally. As this response becomes increasingly international in focus, it is imperative that it be based on assurances that individuals be fairly and properly tried in their home countries before extradition or expulsion proceedings are triggered.

\section{BEING PART OF AN «ORGANIZATION ENGAGED IN ESPIO- NAGE, SUBVERSION OR TERRORISM»}

Any member of a group which engages in the subversion by force of the home government (even if fascistic) will not be granted admission to Canada. Section 19(1)(e) stipulates that no refugee determination hearing will be awarded to:

«persons who there are reasonable grounds to believe are members of an organization that there are reasonable grounds to believe

(A) will engage in acts of espionage or subversion against democratic governments, institutions or processes, as they are understood in Canada;

(B) engage in or instigate the subversion by force of any government; or

(C) engage in terrorism.»

Although there is merit in the policy goal of keeping terrorists out of Canada, s. 19(1)(e) overshoots its mark. Its effect would be to bar many refugee claimants who had simply been politically active in their home countries. Many «liberation organizations» have violent factions. The African National Congress 
or Sinn Fein are but two examples. However, it is unfair to infer that every individual associated with such an organization is somehow «dangerous». Yet the new amendments do precisely this. Any member of an organization that has engaged in terrorist activity, even if the member had nothing to do with it, shall be excluded from the Canadian refugee determination process. S. 19(1)(e) thus establishes an administrative requirement sufficiently unconnected to the actual issue (the merit of the claim) so as to run counter to the substantive component of fundamental justice.

Moreover, there is no provision for any sort of hearing in which the adjudicator or SIO could review the information or allow the claimant to respond to any allegations. Furthermore, the discretion of the decision-maker is absolute in this regard as the Act contains no specific criteria specifying what amount to «reasonable grounds» for a finding of membership in the organization or whether the organization engaged in terrorist activity in the first place. In practice, the determination of what organizations are to be classified as «terrorist» is to be effected by the Canadian Security Intelligence Service (CSIS). ${ }^{123}$ To this end, whereas the «safe third country» provisions violate the procedural guarantees of section 7 in part due to their rigidity, section 19(1)(e) infringes the Charter due to the unfettered discretion it accords the SIO, CSIS and the «adjudicator». 


\section{JUSTIFICATION UNDER SECTION 1 OF THE CHARTER}

Section 1 provides that Charter rights can be subject to limits deemed to be reasonable in a free and democratic society». The test to establish whether a statutory provision constitutes a «reasonable limit» was first delineated by former Chief Justice Dickson in The Queen v. Oakes. ${ }^{124}$ A limitation to a constitutional guarantee will be sustained if two conditions are satisfied. Firstly, the objective of the legislation must be pressing and substantial. Secondly, the means chosen to attain this legislative end must be reasonable and demonstrably justifiable. In order to satisfy the second requirement, the rights violation must be rationally connected to the aim of the legislation, the impugned provision must minimally impair the Charter guarantee, and there must be a proportionality between the effect of the measure and its objective so that the attainment of the legislative goal is not outweighed by the abridgement of the right.

The determination of a «reasonable limit» is a highly contextual process. ${ }^{125}$ The rigidity or even the application of the Oakes test also depends on which Charter right has been violated. For example, a review of Charter jurisprudence indicates that courts are often willing to perceive denials of section 15 as «reasonable limits». On the other hand, section 12 has been held to be an absolute right, a violation thereof thus not capable of being upheld under section $1 .{ }^{126}$ An infringement of section 7 will also be difficult to uphold under s. $1 .{ }^{127}$ In fact, no such infringement has ever been justified as a section 1 «reasonable limit». ${ }^{28}$ Since Bill C-86's most evident Charter violations are those of ss. 7 and 12, the contextual approach makes it more difficult to uphold the legislation under s. 1 .

124. [1986] 1 S.C.R. 103.

125. Edmonton Journal v. Alberta (Attorney General), [1989] 2 S.C.R. 1326, per Wilson J.

126. Smith, supra, note 44, at 105 per McIntyre J. and at 149 per LeDain J.

127. Wilson J. (concurring) in R. v. Swain, [1991] 1 S.C.R. 933 at 1034: «It would be a rare provision which violate[s] the principles of fundamental justice and could nevertheless be justified under s. 1.» Consult also the decision of Sopinka J. in Kindler, supra, note 33, at 18.

128. P.W. Hogg, Constitutional Law of Canada, 1992, Third Edition (Toronto: Carswell), para. 35.14(c), p. 886. 
However, demonstrating the constitutionality of Bill C-86 may be facilitated by the recent Chiarelli decision, in which Mr. Justice Sopinka emphasized that immigration policy is replete with competing interests and suggested that curial deference be awarded to Parliament in this area. The «deferential approach» often arises when the courts are called upon to evaluate the contents of Canada's foreign policy, of which immigration law is a subset. In Allard and Mellino, La Forest J. emphasized that the courts should exercise extreme caution in interfering with the executive's pre-eminent position in matters of external relations. ${ }^{129}$ The point was made that the executive has much greater expertise than the court in the area of foreign affairs. ${ }^{130}$ However, is it not the courts that have both the expertise and the duty to ensure that Charter rights be respected? Furthermore, as stated by Dickson J. (as he then was) in Operation Dismantle v. The Queen, «...disputes of a foreign policy nature may be properly cognizable by the courts.» ${ }^{131}$

\section{a) SAFE THIRD COUNTRY}

The Ministry affirms two overarching objectives to the safe third country provisions: (1) to give effect to a co-ordinated interstate response to the refugee crisis so as to promote comity among nations ${ }^{132}$; (2) to expedite and streamline the refugee determination process in order to cut down «abuse» and promote meritorious claims.

\section{i) CO-ORDINATED INTERSTATE APPROACH}

Even if the promotion of a co-ordinated interstate approach is a pressing and substantial concern, s. 46.01(1) does not pass the second tier of the Oakes test. The fact that s. 46.01(1) the Act is to be administered in so mechanical a way fails to minimally impair the rights of the refugee claimants as they have no

129. The Republic of Argentina v. Mellino, [1987] 1 S.C.R. 536; United States of America v. Allard and Charette (1987), 40 D.L.R. (4th) 102 at 110 (S.C.C.).

130. Mellino, supra, note 129, at 555-6.

131. [1985] 1 S.C.R. 441 at 459.

132. «It is fair to say that refugee determination is a world-wide problem. We need international co-operation to address the root causes of this mass migration», Doug Lewis, Solicitor General, Hansard, 132:163 at 12533, June 22, 1992. 
Canada's new Immigration Act :

opportunity to show whether the «safe third country» is actually safe for them. Without such an opportunity, refugees risk an arbitrary return to their home country. It is difficult to grasp how this could constitute a «reasonable» limit of a fundamental human right.

The violation of the ss. 7, 12 and 15 rights of refugee claimants could not be justified under the policy objective of «the promotion of comity among nations» since there is no rational connection between the stated objective of the statute and s. 46.01(1). For example, the implementation of the «safe third country» provision shall force the United States to hear even more refugee claims than it presently does. In the past, tens of thousands of claimants (especially from Latin America) used the U.S.A. as a springboard to file a claim in Canada. Since s. 46.01(1) eliminates this possibility for most refugees the number of refugee claimants in the United States shall increase. Such unilateral action on Canada's part could in fact disturb (and not promote) the political relationship between Canada and the U.S.A.

What if the «home country» refuses to accept the claimant in question? This individual will then become a «refugee in orbit» and no-one will adjudicate his claim. This does not help rationalize an international problem; if anything, it creates a new one. The Metro Toronto Host Program estimates that $60 \%$ of refugees arriving at Canada's borders pass through the United States or Western Europe. ${ }^{133}$ These individuals will no longer be ex facie entitled to have their claims heard in Canada. Thus, instead of sharing the burden, Bill C-86 shifts more of Canada's responsibilities onto other nations, violating the Geneva Convention's affirmation that «states shall do everything within their power to prevent the refugee problem from becoming a cause of tension between states.» ${ }^{134}$

Moreover, it is hardly a co-ordinated interstate approach to place the entire responsibility of accommodating refugees on the country most geographically proximate to them. Along with transportation contingencies, there are many other reasons why refugees might not want to seek asylum in the first

133. Statistics taken from a document published by the Metro Toronto Host Program in 1992 entitled New Immigration Law Will Keep Refugees Out.

134. 189 U.N.T.S. 137 (No. 2545). 
Canada's new Immigration Act :

country they flee to. Involuntary migrants seek family and communities who can provide both emotional as well as financial support as they attempt to stabilize their lives. ${ }^{135}$ Poorer refugees -- often women -- will be the most affected by the exclusion provision. ${ }^{136}$ By obliging such persons to definitively seek refugee status in the first «safe» country in which they arrive, section 46.01(1) might preclude them from joining the members of their families who have already relocated and settled down in a new home.

In response the Minister could suggest that refugees temporarily in «safe» countries who have family already in Canada would be able to have these family members sponsor them as «family class» immigrants. ${ }^{137}$ Unfortunately, the protection offered to these persons by the «family sponsorship» sections of the Immigration Act is far from complete. There are several conditions precedent that, if left unsatisfied, serve as grounds for the Immigration Officer to deny the sponsorship application. ${ }^{138}$ For example, the family members in Canada might not be able to undertake the required 5 year commitment to provide all necessary care and maintenance to the claimant. The nominee must also demonstrate that she will be able to «establish herself successfully» in Canada. ${ }^{139}$ Only certain family members (spouse, parent, child, siblings, and in some cases more distant relatives) are eligible to sponsor, thereby disadvantaging certain claimants regardless of the urgency of their refugee situation. ${ }^{140} \mathrm{On}$ a broader scale, it is a non-solution to argue that the refugee determination system can be rolled back because refugees can always use the regular immigration procedures. The regular immigration provisions were not designed to deal with the special needs of refugees.

135. Thanks to Susan MacDonald, Faculty of Law, University of Toronto, for this insight as well as the point about the differential effects of Bill C-86 on women refugees.

136. The mechanical nature of the exclusionary provision will disproportionately exclude those unable to afford to come to Canada directly from their home country or those unable to prove to the Canadian government that they have the skills or education to support themselves as independent immigrants. Systemic discrimination in many refugee-producing countries has resulted in women having fewer monetary resources and less education than men.

137. Thanks to Lara Friedlander for this point.

138. Section 77(1) of the Act. Details of these conditions precedent are found in the Regulations. 139. It is unclear what this actually means in practice. Its use could in fact become arbitrary.

140. For example same-sex and common law couples, single persons, and refugees without blood relatives in Canada. 


\section{ii) EXPEDITING AND STREAMLINING THE PRO- CESS}

The second legislative objective of Bill C-86's «safe third country» provision has two wrinkles to it: to ensure that the process set out by the Convention Refugee Determination Division is not abused and that genuine refugees in need of protection be quickly admitted on a cost-effective basis. ${ }^{141}$

Jack Shields, Parliamentary Secretary to the Minister of Employment and Immigration, sums up the government's position on the «abuse» issue:

«What we are trying to stop and what we are going to stop are the bogus claims that are made.» ${ }^{142}$

For the purposes of s. 1, the burden of proof that the government must discharge is that there are sufficient numbers of «bogus» and «abusive» refugee claims so as to characterize the reduction of these claims as a concern of «pressing and substantial» importance. On numerous occasions during the committee stages of Bill C-86 the government was called upon to supply some evidence leading to such a finding. No convincing evidence was presented. To this end, this justification fails to pass the first stage of the Oakes test. ${ }^{143}$

The second wrinkle involves time management and economics. The Ministry felt that continuing to administer hearings to all claimants would simply be too expensive given the recessionary nature of the Canadian economy. If the government seeks a justification for the safe third country provision in the realm of administrative efficiency and expediency, its attention must be drawn to the judgement of Wilson J. in Singh:

«The guarantees of the Charter would be illusory if they could be ignored because it was administratively convenient to do so. No doubt considerable time and money can be saved by adopting administrative

141. Refugee Affairs Division, Refugee Perspectives, 1987-88, (Ottawa: The Division, 1988) at 36.

142. Hansard, 132:163 at 12507, June 22, 1992.

143. The Oakes test is summarized earlier in this essay in the text following note 124 . 
Canada's new Immigration Act :

procedures which ignore the principles of fundamental justice, but such an argument, in my view, misses the point of the exercise under s. $1 .{ }^{144}$

Even if administrative expediency constituted a «pressing and substantial» objective, the numbers of refugees arriving at Canada's borders are hardly large enough to warrant the drastic «weeding out» measures proposed by Bill C86. Once again, the legislation fails the second tier of the Oakes test by overshooting its mark. In 1992, only 44,000 refugee claimants arrived at Canada's borders, 30,000 of these arriving through safe third countries. This is far lower than most European countries whose population densities are much higher than Canada's. According to the Metro Toronto Host Program, in 1991 Canada received 1.11 asylum seekers for every 1000 Canadians. This can be compared to 6.3 for Switzerland, 3.6 for Austria, 3.3 for Germany and 3.18 for Sweden. ${ }^{145}$ Canada even receives fewer refugee claimants per capita than many developing countries. Yet Bill C-86 could reduce the number of refugee claimants allowed to present their claim in Canada by as much as $68 \% !^{146}$ If any backlog has arisen within the refugee determination system, it seems unfair to eliminate the government's own prior inefficiency at the expense of fundamental justice for future claimants.

However, one legitimate goal within the domain of administrative expediency is the reduction of the review process for refugee claimants. At present, there is a lag of about 14 months between arrival in Canada and the final decision regarding the claim. The Ministry, through Bill C-86, seeks to reduce this to an average of 6 months. Nevertheless, this goal can be more effectively attained through means less intrusive than Bill C-86. ${ }^{147}$

144. Singh, supra, note 6, 58 N.R. at 69. The same point was echoed by the Supreme Court in $R$. v. Schwartz, [1988] 2 S.C.R. 443 at 472.

145. Statistics taken from a document published by the Metro Toronto Host Program in 1992 entitled New Immigration Law Will Keep Refugees Out.

146. Since 30,000 out of the 44,000 claimants arriving to Canada in 1992 «passed through» safe third countries and the new provisions could exclude almost all of them, a figure of $68 \%$ is arrived at.

147. The solution lies not in expelling large numbers of claimants as soon as they arrive. There are more constructive approaches. For example, an effort might be made to reducing certain steps in the permanent residence determination process, given that the consequences on the applicants are less severe. This could allow more Immigration Officers to sit on refugee 


\section{b) PRIOR CRIMINAL RECORD AND SUBVERSIVE ORGANIZATION}

The objective of the «prior criminal record» and «subversion» provisions is the preservation of Canadian national security ${ }^{148}$ :

«We are not going to become as a country a safe haven for retired or active terrorists...the legislation is going to close the door on those individuals... [and] assist the RCMP and other police forces in their battle with organized crime.» ${ }^{149}$

«[The former Immigration Act] put the very safety and security of Canadians at risk...we have to face the fact that the world of the 1990's is a world of increasingly sophisticated, internationally organized criminals and terrorists. New measures will strengthen the definition of criminal inadmissibility and allow us to keep out people...known to be part of a terrorist organization. They will give Immigration Officers the authority to refuse entry to anyone involved in [these] activities.» ${ }^{150}$

However, section 19(1)(c.1)(i) is not rationally connected to this objective as no allowance is made to determine whether those claimants kept out of Canada have been fairly convicted (and hence whether they are actually «criminal»). The second tier of the Oakes test is thus not satisfied. Nor is the

cases, thus allowing for more hearings to take place at the same time. Another approach would be to reallocate judicial and administrative resources to Refugee Determination Boards and away from other public tribunals due to the heightened seriousness of the consequences of refugee decisions.

In The Queen v. Chaulk (1990), 62 C.C.C. (3d) 193, Lamer C.J.C. lessened the stringency of the «least restrictive means» test. He held at 221 that «when assessing the alternative means which were available to Parliament, it is important to consider whether a less intrusive means would achieve the same objective as effectively». The alternative means suggested to reduce the «waiting period», since they attain the legislative goal just as effectively, indicate that Bill C-86 does not satisfy even the less stringent s. 1 test found in Chaulk.

148. A hidden policy objective could be the keeping out of Canada of politically involved dissidents.

149. Hon. Doug Lewis, Solicitor General, Hansard, 132:163 at 12533, June 22, 1992.

150. Jack Shields, Parliamentary Secretary to the Minister of Employment and Immigration, Hansard, 132:163 at 12504-5, June 22, 1992. 
effect of the legislation proportionate to its goal. The number of international criminals trying to enter Canada (as in the recent case of the Hong Kong triad members ${ }^{151}$ ) is simply not sufficient to require such a drastic measure. Moreover, even if the numbers were sufficient, legislative drafters cannot assume that foreign countries have fair judicial proceedings just so that Canadian immigration procedures can be expedited. It is imperative to keep in mind the words of Laskin J. (as he then was) in his 1973 judgement in Minister of Manpower and Immigration v. Brooks :

«[The law of another country] cannot be controlling in relation to an inquiry about criminal convictions to determine whether immigration to Canada should be permitted.» ${ }^{152}$

The same shortcoming affects s. 19(1)(e). Although it may be «demonstrably justifiable» to expel someone known to have personally engaged in terrorism, Bill C-86 overshoots its mark by excluding anyone simply believed to be part of an organization having engaged in CSIS's ${ }^{153}$ definition of «subversive terrorism».

In conclusion, although immigration policy involves balancing the interests of the individual claimant and the state, these are not necessarily at odds with each other. Fair hearings in which claims are entitled to be properly presented maximizes fundamental justice for all refugees. Such a procedure allows the most meritorious claimants to enter Canada and not be excluded on the basis of connecting flights or unfair convictions. In the long run the state, too, benefits from this.

\section{FILLING THE VOID}

If s. 46.01(1), 19(1)(c.1)(i) and 19(1)(e) of the Immigration Act are struck down as unconstitutional, a void is created. Although the Act will continue to apply, it shall do so without any provisions governing the admissibi-

151. «Triad menace an iceberg, reports warn», The Globe and Mail, Wednesday, March 10, 1993, p. A1.

152. 36 D.L.R. (3d) 522 at 531.

153. Consult note 123 . 
lity of certain classes of refugee claimants that it had hitherto excluded. This may very well be the intention of the courts, as a situation is created in which persons arriving from «safe third countries» and with «prior convictions» are allowed to enter the refugee determination system, with the possibility that these factors operate to affect the actual merit based decision as to whether Canada should award them refugee asylum. However, a more constructive solution might take the form of judicial intervention so as to preserve the constitutionality of the impugned legislation.

There are two possible approaches. In $R$. v. Seaboyer ${ }^{154}$, McLachlin J., after striking down s. 276 of the Criminal Code, replaced it with a set of judicially created guidelines she suggested would have to be incorporated into any future legislation on the subject of restrictions on the use of prior sexual history of complainants in sexual assault cases in order for these to sustain Charter scrutiny.

However, in other situations courts have gone even further and have actually «read in» terms to statutory provisions. In Haig v. Canada ${ }^{155}$ the Ontario Court of Appeal inserted clauses into a statute in order to preserve its constitutionality. In fact, this approach has been sanctioned by the Supreme Court in its 1992 decision in Schachter v. Canada. ${ }^{156}$ Although a highly efficient form of remedying constitutional wrongs, serious concerns can be raised with regard to how comfortable we may be with the judiciary acting as pseudo-legislatures. The Supreme Court was sensitive to this issue in Schachter. Lamer J. outlined a procedure to be followed should only part of a statute or provision violate the Constitution. ${ }^{157}$ This procedure stipulates that the courts should only «read in» when such activity does not change the nature of the legislative scheme in question. In a difficult situation (as was the case in Schachter itself), the court should feel free to strike down the unconstitutional provision yet suspend the declaration of invalidity so as to give the government time to respond.

154. $\quad R$. v. Seaboyer, [1991] 2 S.C.R. 577.

155. (1992), 9 O.R. (3d) 495 (C.A.).

156. [1992] 2 S.C.R. 679 at 702.

157. $\quad I d$., at 717 to 719 . 
The «guidelines» or «reading in» approach might be particularly applicable in the case of Bill C-86 due to the fact that any potential Charter violations could be remedied through the insertion of procedural and other protections into the Act. For example, courts could «read in» a requirement to seek assurances from the «safe third country» as to the holding of a fair hearing. On a similar note, if rights to hearings, counsel, interpreters and appeals were included in both s. 46.01(1) and 19(1)(c.1)(i), then the requirements of fundamental justice under Singh and Hofer would be met. The introduction of a sensitive equivalency of procedures test might also inject fundamental justice into the «prior conviction» exclusion as well as eliminate the possibility that cruel and unusual punishment could result from returning a claimant to her place of origin due to a fraudulent conviction.

This judicial approach could guarantee refugee claimants Charter rights while at the same time enabling the government to pursue the legitimate policy goals behind the Immigration Act. These include the maintenance of international comity in the area of refugee law, cutting down the waiting period for refugee claims to be processed, and recognizing that a globally co-ordinated response to refugee claimants is preferable over an amalgam of disjointed national ones. However, if the effect of «reading in» would be to significantly change the nature of the refugee determination scheme beyond the intentions of the legislature, then the Schachter «suspended declaration of invalidity» might be a better way to proceed. This would empower Parliament to maintain the constitutionality of Bill C-86 through means it is comfortable with or even invoke its power under the notwithstanding clause.

\section{E. CONCLUSION}

The «safe third country» and «prior criminal record» amendments to the Immigration Act proposed by Bill C-86 appear to violate some of the Charter's cardinal principles. It is ironic that the Act parrots the guarantees of the Geneva Convention in matters of refugee determination yet circumvents these by keeping claimants outside of the refugee determination process in the first place. $^{158}$

158. Consult ss. 2, 3(g) and 53 of the Immigration Act, S.C. 1991, c. I-2. 
Immigration law is rapidly becoming a central focus of public policy debate in Canada. Within this debate importance should be attributed to the fact that a balance must be maintained between any restructuring of Canada's immigration policies and the rights accorded refugees by the Charter and the Geneva Convention. In this sense, these rights documents can serve a pivotal role in helping governments develop legislative initiatives that are better tailored to their policy goals, thereby promoting both the individual as well as collective interests.

The same government (in fact, the same Minister, Bernard Valcourt) that passed Bill C-86 was persuaded in March 1993 to allow «violence against women» to be a reason supporting a claim of refugee status in Canada. ${ }^{159}$ This shows the potential effect of public lobbying. In a similar spirit, political pressure or legal challenges could help rework s. 46.01(1) and s. 19(1)(c.1)(i) and thus ensure that Canada's integrity in the area of refugee policy be maintained.

159. «Domestic abuse accepted for refugee status», Globe and Mail, Wednesday, March 10, 1993, p. A1. 